\title{
GAMBARAN FUNGSI KOGNITIF PADA LANJUT USIA (LANSIA)
}

\author{
${ }^{1}$ Andria Pragholapati, ${ }^{2}$ Firna Ardiana, ${ }^{3}$ Lia Nurlianawati \\ ${ }^{1,2,3}$ Nursing Department, Universitas Pendidikan Indonesia, Bandung, Indonesia \\ Email: andria.pragholapati@upi.edu
}

\begin{abstract}
Indonesia is among the countries that entered the aging structured population because there were $7.18 \%$ of 60 years over the Elderly population. The increase in the Elderly population caused some problems. The biggest problem in the Elderly was degenerative diseases, physical changes appeared when people grow old. One of those changes was in anatomy and atrophy neurological system which progressively decreases the cognitive function. Cognitive function was an ability to think, to remembered, to learn, communicated, and solved problems. The purpose of this research was to describe the cognitive function and used descriptive design research. This study design was descriptive quantitative. Engineering sampling using purposive sampling. The population of this research was 56 people (34 in Panti Jompo Muhammadiyah and 22 in Yayasan Pondok Lansia Tulus Kasih) and almost 36 people participated. The data collecting technique used the MoCA Ina questionnaire with univariate frequency using distribution analysis. The result showed that almost half of them (47.2\%) suffered from dementia Alzheimer of severed cognitive disorder. Based on this research suggested to Panti manager to make efforts to increases the cognitive function of the Elderly such as a brain gym and a relaxing way.
\end{abstract}

\section{Keywords : Elderly, Cognitive function, MoCA-Ina}

\section{PENDAHULUAN}

Indonesia termasuk negara yang memasuki penduduk berstruktur lanjut usia (aging structured population) karena jumlah penduduk yang berusia 60 tahun ke atas sekitar 7,18\%. Jumlah penduduk lansia di Indonesia pada tahun 2006 sebesar 19 juta, dengan usia harapan hidup 66,2 tahun. Sementara pada tahun 2011 jumlah lansia sebesar 20 juta jiwa $(9,51 \%)$ dengan usia harapan hidup 67,4 tahun (Departemen Kesehatan, 2012).

Badan pusat statistik memperkirakan tahun 2020 lanjut usia di Indonesia akan berjumlah 28,8 juta atau $11,34 \%$ dari jumlah penduduk Indonesia, pertumbuhan jumlah lanjut usia di Indonesia tercatat paling pesat di dunia dalam kurun waktu tahun 19902025 (Departemen Kesehatan, 2012).
Kelompok lanjut usia adalah kelompok penduduk berusia 60 tahun keatas. Jumlah penduduk lanjut usia yang ada di jawa barat yang tercatat oleh dinas sosial jawa baratyaitu 3,4 juta orang atau setara dengan $8 \%$ dari jumlah penduduk jawa barat (Dinas Sosial, 2013).

Meningkatnya populasi lanjut usia ini membuat pemerintah perlu merumuskan kebijakan dan program yang ditujukan kepada kelompok penduduk lanjut usia sehingga dapat berperan dalam pembangunan dan tidak menjadi beban bagi masyarakat. Pertumbuhan lanjut usia pada negara berkembang lebih tinggi dari negara yang sudah berkembang masalah terbesar lanjut usia adalah penyakit degeneratif, diperkirakan pada tahun 2020 sekitar $75 \%$ lanjut usia penderita penyakit degeneratif 
tidak dapat beraktifitas (Pusdatin Kemenkes RI, 2013).

Lanjut usia adalah bagian dari proses tumbuh kembang. Manusia tidak secara tibatiba menjadi tua, tetapi berkembang dari bayi, anak-anak, dewasa dan akhirnya menjadi tua. Hal ini normal, dengan perubahan fisik dan tingkah laku yang dapat diramalkan yang terjadi pada semua orang pada saat mereka mencapai usia tahap perkembangan kronologis tertentu (Azizah, 2011).

Semakin bertambahnya umur manusia, terjadi proses penuaan secara degeneratif yang akan berdampak pada perubahanperubahan pada manusia, tidak hanya perubahan fisik, tetapi juga kognitif, perasaan sosial dan seksual. Perubahan fisik meliputi sistem indra, sistem muskuloskeletal, sistem kardiovaskuler dan respirasi, pencernaan dan metabolisme, sistem perkemihan, sistem saraf, dan sistem reproduksi (Azizah, 2011).

Sistem susunan saraf mengalami perubahan anatomi dan atrofi yang progresif pada serabut saraf lanjut usia. Lanjut usia mengalami penurunan koordinasi dan kemampuan dalam melakukan aktivitas sehari-hari. Penuaan menyebabkan penurunan persepsi sensori dan respon motorik pada susunan saraf pusat, hal ini terjadi karena susunan saraf pusat pada lanjut usia mengalami perubahan yang mengakibatkan penurunan fungsi kognitif (Azizah, 2011).

Fungsi kognitif merupakan kemampuan berpikir, mengingat, belajar, menggunakan bahasa, memori, pertimbangan, pemecahan masalah, serta kemampuan eksekutif seperti merencanakan, menilai, mengawasi, dan melakukan evaluasi (Strub \& Black,
2000; Rizzo et al, 2004, dalam Tambunan, 2013).

Kemunduran fungsi kognitif dapat berupa mudah lupa (Forgetfulness) yaitu bentuk gangguan kognitif yang paling ringan di perkirakan di keluhkan oleh 39\% lansia yang berusia 50-59 tahun, meningkatmenjadi $85 \%$ pada usia lebih dari 80 tahun. Di fase ini seseorang masih bisa berfungsinormal yaitu mulai sulit mengingat kembali informasi yang telah di pelajari, tidak jarang di temukan oleh orang setengah baya. Jika penduduk berusia lebih dari 60 tahun di indonesia berjumlah $7 \%$ dari seluluh penduduk, maka keluhan mudah lupa tersebut di derita oleh sekitar 3\% populasi di indonesia. Mudah lupa inidapat berlanjut menjadi Gangguan Kognitif Ringan (Mild Cognitive Imprairment MCI) sampai ke demensia sebagai bentuk klinisyang paling berat (Wreksoatmodjo, 2010 dalam Yeni, 2010).

Faktor-faktor yang mempengaruhi fungsi kognitif yaitu usia, jenis kelamin, status mental dan emosional., aktivitas fisik dan olahraga, pendidikan, kondisi lingkungan. (Wade \& Travis 2007; Wang \& Dong 2005 dalam Yao et al 2009; Susanto 2009; Asih 2013).

Dampak penurunan fungsi kognitif pada lansia yaitu lansia dapat melupakan identitasnya, melupakan nama anggota keluarganya, lansia tidak dapat melakukan aktivitas sehari-hari seperti makan, minum, mandi, mempengaruhi produktifitas, dan mempengaruhi tingkat kemandirian (Zulsita, 2010). Selain itu penurunan fungsi kognitif pada lanjut usia berasosiasi secara signifikan dengan peningkatan depresi dan memiliki dampak terhadap kualitas hidup yang buruk pada lansia (Aartsen, Van Tilburg, Smits, \& 
Knipscheer, 2004 dalam Surprenant \& Neath, 2007).

Penanganan pada gangguan fungsi kognitif normal dengan cara peningkatan memori (daya ingat) dapat dilakukan dengan cara seperti mencatat sesuatu pada daftar, kalender atau buku catatan (Tamher dan Noorkasiani, 2009). Penanganan pada MCI (Mild Cognitive Impairment)/gangguan fungsi kognitif ringan dengan cara mengembangkan hobbi yang ada seperti melukis, memasak, main musik, berkebun, mengikuti aktivitas keagamaan, olah raga dan hindari stres (Azizah, 2011). Penanganan pada Demensia Alzheimer/gangguan fungsi kognitif berat dengan cara hindari situasi yang memprovokasi, hindari argumentasi, psikoterapi individual, psiko terapi kelompok, dukungan mental, pengembangan kemampuan adaptasi dan peningkatan kemandirian, kemampuan menerima kenyataan, yakinkan dimana keberadaan pasien, terapi obat dengan pengawasan dokter (Azizah, 2011).

Populasi lanjut usia 10\% sampai $15 \%$ yang berusia lebih dari 65 tahun dan hampir $50 \%$ populasi berusia lebih dari 85 tahun mengalami perubahan kognitif seperti demensia, kelainan ini merupakan masalah yang terjadi dan serius. Kelainan status kognitif cepat meluas pada usia lanjut dan diperkirakan pada tahun 2050 akan mengalami peningkatan kurang lebih 14 juta penderita gangguan kognitif (Muttaqin, 2008).

Berdasarkan penelitian yang dilakukan Heni Maryati tanggal 9 Mei 2013 di UPT Panti Werdha Mojopahit Mojokerto mengenai gambaran fungsi kognitif pada lansia metode pengumpulan data dengan wawancara terbimbing menggunakan Mini
Mental State Exam (MMSE) dari hasil penelitian didapatkan data hampir setengahnya $46,7 \%$ lansia mengalami perubahan fungsi kognitif berat.

Menurut data Rekam Medis di salah satu Puskesmas di Surabaya (Puskesmas Sidosermo) terdapat 218 lansia dengan umur bervariasi dan rata-rata $(60 \%)$ mengalami penurunan fungsi kognitif seperti penurunan orientasi lupa tanggal berapa sekarang, penurunan kemampuan berhitung atau mengeja kata dari belakang, dan penurunan kemampuan recall atau menyebutkankembali nama benda (Sya'diyah, 2010).

Menurut penelitian di Inggris, dari 10.255 orang lansia, $45 \%$ mengalami gangguan fungsi kognitif pada susunan saraf pusat (Nugroho, 2008). Suatu penelitian yang dilakukan di Negara Inggris dengan jumlah responden 10.255 orang lansiadiatas 75 tahun, menunjukkan bahwa 55\% lansia mengalami gangguan fisik berupa arthritis atau gangguan sendi $50 \%$ dari responden mengalami keseimbangan berdiri, $45 \%$ dari responden mengalami gangguan fungsi kognitif pada susunan saraf pusat, 35\% pada penglihatan, $35 \%$ pada pendengaran, $20 \%$ mengalami kelainanjantung, 20\% ditemukan sesak napas, serta gangguan miksi atau ngompol sebesar 10\%, dari beberapa gangguan yang terjadi pada lansia dapat mengakibatkan terganggunya atau menurunnya kualitas hidup pada lansia. Kemunduran yang paling banyak ditemukan adalah menurunnya kemampuan memori daya ingat (Foster, 2011).

Untuk meningkatkan harapan hidup lansia maka pemerintah merumuskan kebijakan membuat panti agar lansia bisa terawat dan terperhatikan baik yang dikelola dalam pemerintah ataupun swasta. Panti Jompo Muhammadiyah adalah panti yang 
ada di daerah bandung tepatnya di rancabolang jumlah lansianya ada 34 orang, sebagian lansia yang ada di panti tersebut tinggal dirumahnya sendiri, ketika ada suatu acara mereka berkumpul dirumah ketuapanti pada saat selesai acara mereka pulang ada beberapa lansia yang lupa jalan pulang. Dan di daerah bandung juga ada panti yang bernama Yayasan pondok lansia tulus kasih yang lebih tepatnya ada di jalan sarijadi bandung jumlah lansianya ada 22 orang selain panti Muhammadiyah, panti ini juga memiliki lansia yang mengalami tanda-tanda penurunan fungsi kognitif, panti ini belum pernah diukur fungsi kognitif oleh MoCAIna dan belum ada penellitian. Jumlah lansiayang ada di dua panti tersebut yaitu 56 orang.

Berdasarkan hasil studi pendahuluan yang dilakukan di Panti Jompo Muhammadiyah menurut pengurus panti ada 1 orang lansia salah terus masuk kamar temannya. Studi pendahuluan di yayasan pondok lansia tulus kasih ada 1 orang lansia tidak ingat kejadian yang baru saja terjadi tetapi ketika ditanya masa lalunya dia menceritakannya dengan lancar.

Berdasarkan wawancara peneliti didapatkan dari Panti Jompo Muhammadiyah dari 2 orang lansia, 1 orang tidak ingat tanggal, 1 orang ketika diajak berkomunikasi pertanyaan dan jawaban tidak sinkron dan dari yayasan pondoklansia tulus kasih dari 2 orang, 1 orang mengulangngulang pertanyaan dan 1 orang sulit berkonsentrasi pada saat diajak berkomunikasi.

Berdasarkan hasil observasi di Panti Jompo Muhammadiyah ada 1 orang lansia yang kadang-kadang mau berkomunikasi kadang-kadang tidak, 1 orang lansia yang diam terus tidak mau ikut kegiatan panti, 1 orang lansia yang selalu nanya-nanya ke temannya dimana kamarnya dan berdasarkan observasi di Yayasan PondokLansia Tulus Kasih ada 2 orang lansia yang mandinya dimandikan, 2 orang lansia yang makannya disuapin untuk mengetahui fungsi kognitif maka perlu pemerikasaan dengan menggunakan MoCA Ina.

Montreal Cognitive Assesment (MoCA Ina) adalah alat skrining kognitif baru yang dirancang untuk mengatasi keterbatasan MMSE. Kelebihan tes MoCA Ina adalah prosedur yang cepat dan mudah, penilaian domain kognitif yang luas dan lebih sensitif terhadap defisit kognitif ringan. Montreal Cognitive Assesment-Versi Indonesia (MoCA-Ina) yang mengukur fungsi kognitif pada lansia. Skala ini dikembangkan oleh Z. Nasreddine dan telah divalidasi di Indonesia. MoCA-Ina memiliki keunggulan dibandingkan Mini Mental State Examination (MMSE) dalam mendeteksi adanya MCI dalam populasi (Chou et al., 2010).

Berdasarkan latar belakang diataspeneliti tertarik untuk melakukan penelitian tentang gambaran fungsi kognitif pada Lanjut Usia (Lansia) di Panti Jompo Muhammadiyah dan Yayasan Pondok Lansia Tulus Kasih.

\section{METODE PENELITIAN}

Rancangan Penelitian ini bersifat deskriptif kuantitatif yang bertujuan untuk menggambarkan terhadap objek yang diteliti melalui data sampel atau populasi sebagaimana adanya "Gambaran fungsi kognitif pada lanjut usia (lansia) di Panti Jompo Muhammadiyah dan YayasanPondok Lansia Kasih" 
Populasi dalam penelitian ini adalah lansia yang ada di Panti Jompo Muhammadiyah dan Yayasan Pondok Lansia Tulus Kasih. Jumlah lansia di Panti Jompo Muhammadiyah 34 orang dan Yayasan Pondok Lansia Tulus kasih jumlah lansianya ada 22 orang jadi jumlah lansia yang ada di dua panti tersebut adalah 56 orang. Penelitian ini menggunakan tehnik purposive sampling. Agar karakteriktik sampel tidak menyimpang dari populasinya, maka sebelum dilakukan pengambilan sampel perlu ditentukan kriteria inklusi maupun kriteria eklusi. Sampel dalam penelitian ini sebanyak 36 orang. Kriteria inklusi dalam penelitian ini adalah sebagai berikut:

a. Bersedia menjadi responden

b. Lanjut usia yang mencapai usia 60 (enam puluh) tahun ke atas

c. Dapat diajak berkomunikasi secara verbal

d. Lanjut usia bisa baca tulis

Kriteria ekslusi dalam penelitian ini adalah sebagai berikut:

a. Lanjut usia yang tidak bersedia menjadi responden

b. Lanjut usia yang mengalami gangguan psikologis

c. Lanjut usia yang sedang sakit
Untuk mengetahui Fungsi kognitif pada lanjut usia (lansia) yang ada di Panti Jompo Muhammadiyah dan Yayasan Pondok Lansia Tulus Kasih dengan menggunakan Kuesioner MoCA Ina (Montreal Cognitive Assesment-Versi Indonesia) (Nasreddine, 1996 dalam Panentu dan Irfan, 2013).

Pada penelitian ini tidak melakukan uji validitas dan peneliti tidak melakukan modifikasi karena kuesioner MoCA Inasudah baku ( $\mathrm{p}=0,000)$ (Panentu dan Irfan, 2013). Pada penelitian ini tidak melakukan uji reliabilitas dan peneliti tidak melakukan modifikasi karena kuesioner MoCA Inasudah baku ( $r=0,963)$ (Panentu dan Irfan, 2013).

Kode etik penelitian adalah satu pedoman yang berlaku untuk setiap kegiatan penelitian yang melibatkan pihak penelti, pihak yang diteliti, dan masyarakat yang memperoleh dampak penelitian tersebut (Notoatmodjo, 2012).

\section{HASIL}

Tabel 1. Gambaran fungsi kognitif pada lansia di Panti Jompo Muhammadiyah

\begin{tabular}{lcc}
\hline \multicolumn{1}{c}{ Fungsi kognitif } & f & \% \\
\hline MCI & 5 & 27.8 \\
Demensia Alzheimer & 13 & 72.2 \\
Total & 18 & 100.0 \\
\hline
\end{tabular}

Tabel 1 diatas menunjukan bahwa sebagian besar lansia (72.2\%) mengalami Demensia Alzheimer. 
Tabel 2. Gambaran fungsi kognitif pada lansia di Yayasan Pondok Lansia Tulus Kasih

\begin{tabular}{lcc}
\hline \multicolumn{1}{c}{ Fungsi kognitif } & f & \% \\
\hline Normal & 5 & 27.8 \\
MCI & 9 & 50.0 \\
Demensia Alzheimer & 4 & 22.2 \\
Total & 18 & 100.0 \\
\hline
\end{tabular}

Tabel 2 diatas menunjukan bahwa setengahnya lansia (50.0\%) mengalami MCI (Mild Cognitive Impairment) atau gangguan fungsi kognitif ringan.

Tabel 3. Gambaran fungsi kognitif pada lansia di Panti Jompo Muhammadiyah dan Yayasan Pondok Lansia Tulus Kasih

\begin{tabular}{lcc}
\hline \multicolumn{1}{c}{ Fungsi Kognitif } & f & \% \\
\hline Normal & 5 & 13.9 \\
MCI & 14 & 38.9 \\
Demensia Alzheimer & 17 & 47.2 \\
Total & 36 & 100 \\
\hline
\end{tabular}

Tabel 3 diatas menunjukan bahwa hampir setengahnya lansia (47.25) mengalami Demensia Alzheimer atau gangguan kognitif berat.

\section{PEMBAHASAN}

\section{a. Gambaran fungsi kognitif pada lansia di Panti Jompo Muhammadiyah}

Hasil penelitian yang di dapatkan di Panti Jompo Muhammadiyah yaitu hampir setengahnya MCI atau gangguan kognitif ringan 5 lansia $(27,8 \%)$ dan sebagian besar Demensia Alzheimer yaitu 13 lansia (72,2\%). Lansia yang MCI adalah lansia yang mempunyai aktifitas yang bagus, yang aktif melakukan kegiatan sehari-hari baik kegiatan dipanti maupun lansia yang ada dirumahnya, dan lansia yang mengalami demensia berpendidikan rendah, pada saatmelakukan penelitian karena dilakukan disatu ruangan saat satu lansia dibimbing untuk mengisi kuesioner lansia yang lainnyamengobrol dan saling bercanda sehingga lingkungannya bising dan tidak kondusif.

\section{b. Gambaran fungsi kognitif pada lansia di Yayasan Pondok Lansia Tulus Kasih}

Hasil penelitian yang di dapatkan di Yayasan Pondok Lansia Tulus Kasih yaitu hampir setengahnya Normal 5 lansia $(27,8 \%)$, hampir setengahnya lansia MCI atau gangguan kognitif ringan 9 lansia $(50.0 \%)$ dan sebagian kecil Demensia Alzheimer yaitu 4 lansia (22,2\%). Lansia yang fungsi kognitifnya normal adalah lansia yang berpendidikan tinggi serta yang aktivitasnya bagus, Lansia yang MCI adalah lansia yang mempunyai pendidikan tinggi tetapi karena umurnya sudah lebih dari delapan puluh maka tidak dapat dipungkiri terjadi penurunan fungsi kognitif dan lansia yang demensia adalah lansia yang pendidikan rendah, pada saat penelitian lansia yang sedang berkumpuln dihalaman 
panti tetapi ketika mengisi kuesioner satu persatu lansia masuk ke sebuah ruangan sehingga diruangan itu tidak terlalu bising dan lansia bisa konsentrasi menjawab atau mengikuti apa yang diperintahkan.

\section{c. Gambaran fungsi kognitif pada lansia di Panti Jompo Muhammadiyah dan Yayasan Pondok Lansia Tulus Kasih}

Hasil analisa univariat pada variabel fungsi kognitif diketahui bahwa sebagian kecil lansia fungsi kognitifnya normal yaitu 5 lansia (13.9\%), hampir setengahnya lansia MCI atau gangguan kognitif ringan yaitu 14 lansia (38.9\%) hampir setengahnya lansia mengalami demensia alzheimer atau gangguan kognitif berat yaitu 17 lansia $(47.2 \%)$.

Lansia yang fungsi kognitifnya normal adalah lansia yang memiliki pendidikanyang tinggi seperti S1, Diploma, adapun yang smp memiliki fungsi kognitif normal karena lansia ini aktif dalam mengikuti kegiatankegiatan yang diadakan di panti, lansia yang gangguan kognitif ringan atau MCI ini kebanyakan berpendidikan tinggi tetapi mungkin karna dilihat dari usia juga delapan puluh keatas yang mengakibatkanpenurunan fungsi kognitif dan untuk lansia yang demensia atau gangguan kognitif berat $99 \%$ berpendidikan SD (sekolah dasar) ketika dikaji menggunakan kuesioner lansia yang mengalami demensia dalam berhitungnya sangat lemah bahkan ada pula yang tidak bisa jawab pada saat disuruh berhitung, begitupun dalam hal mengingatkata-kata lansia susah menjawab dan menyerah karna dia tidak mampu lagi untuk mengingat apa yang harus dihapalkan.

Fungsi kognitif merupakan kemampuan berpikir, mengingat, belajar, menggunakan bahasa, memori, pertimbangan, pemecahan masalah, serta kemampuan eksekutif seperti merencanakan, menilai, mengawasi, dan melakukan evaluasi. Fungsi kognitif normal gejalanya adalah proses berpikir lamban dan sulit untuk berkonsentrasi, sulit mempelajari informasi baru, mudah lupa nama benda atau orang, lebih sering menjabarkan bentukatau fungsi ketimbang menyebutkan namanya. Gangguan fungsi kognitif ringan (mild cognitive impairment $=\mathrm{MCI}$ ) Gangguan fungsi kognitif terlihat lebih nyata, dengan gejala utamanya adalah gangguan pada ingatan jangka pendek. Akibatnya penderita sering lupa terhadap kegiatan yang baru saja terjadi atau mengulang-ulang pertanyaan. Hal ini yang menyebabkan kasus MCI sering luput dari pengamatan, padahal MCI merupakan petanda dini dari demensia. Lebih dari $50 \%$ penderita MCI berkembang menjadi demensia dalam $3-5$ tahun (Dharmono dkk, 2008).

Kemunduran fungsi kognitif dapat berupa mudah lupa (Forgetfulness) yaitu bentuk gangguan kognitif yang paling ringan di perkirakan di keluhkan oleh 39\% lansia yang berusia 50-59 tahun, meningkatmenjadi $85 \%$ pada usia lebih dari 80 tahun. Di fase ini seseorang masih bisa berfungsi normal yaitu mulai sulit mengingat kembali informasi yang telah di pelajari, tidak jarang di temukan oleh orang setengah baya. Jika penduduk berusia lebih dari 60 tahun di indonesia berjumlah $7 \%$ dari seluluh penduduk, maka keluhan mudah lupa tersebut di derita oleh sekitar 3\% populasi di indonesia. Mudah lupa inidapat berlanjut menjadi Gangguan Kognitif Ringan (Mild Cognitive Imprairment MCI) sampai ke demensia sebagai bentuk klinisyang paling berat (Wreksoatmodjo, 2010 dalam Yeni , 2010).

Populasi lanjut usia $10 \%$ sampai $15 \%$ yang berusia lebih dari 65 tahun dan hampir $50 \%$ populasi berusia lebih dari 85 tahun mengalami perubahan kognitif seperti demensia, kelainan ini merupakan masalah yang terjadi dan serius. Kelainan status kognitif cepat meluas pada usia lanjut dan diperkirakan pada tahun 2050 akan 
mengalami peningkatan kurang lebih 14 juta penderita gangguan kognitif

Hal ini juga sependapat denga hasil penelitian Heni Maryati, (2013) sebagian besar $(70 \%)$ berjenis kelamin perempuan, sebagian besar $(56,7 \%)$ berusia antara $60-74$ tahun, hampir setengahnya $(36,7 \%)$ tidak bersekolah. Hampir setengahnya $(46,7 \%)$ mengalami perubahan fungsi kognitif berat. Secara umum faktor yang mempengaruhi fungsi kognitif pada seseorang adalah penurunan fungsi sistem saraf. Jika sistem saraf pada seseorang terganggu maka secara otomatis ataupun secara tidak langsung fungsi kognitifnya pasti akan menurun. Maka dari itu pada lansia pasti mengalami proses penuaan yang berakibat pada penurunan kemampuan fungsi tubuh salah satunya adalah sistem saraf yang dapat berakibat pada kemampuan fungsi kognitif pada lansia mengalami penurunan fungsi kognitif ringan ataupun berat.

Dilihat dari hasil peneliti menyimpulkan bahwa usia dapat mempengaruhi fungsi kognitif lansia yang usianya lebih dari delapan puluh tahun kemampuan untuk berpikir dan untuk menjawab pertanyaan lambat apa lagi ketika lansianya hanya berpendidikan sekolah dasar dan usianya lebih dari delapan puluh maka hasilnya sangat sedikit, wanita lebih banyak mengalami fungsi kognitif karna di dua panti tersebut didominasi oleh lansia yang berjenis kelamin perempuan, dan pendidikan mempengaruhi fungsi kognitif sesuai dengan yang peneliti dapatkan lansia yang berpendidikan sekolah dasar dalam kemampuan berhitungnya sangat lambat, kemampuan mengingatnya sangat kurang, dalam mengulangi kalimat yang peneliti sebutkan itu tidak sesuai dengan apa yang disuruh, dalam mengingat hari, tanggal, bulan, tahun tidak ingat sedangkan lansia yang berpendidikan tinggi mereka mampu berhitung. Ada salah satu dari lansia yang pendidikannya tinggi pada saat ngisi kuesioner jawaban dalam berhitungnyabenar semua, begitupun kemampuan dalam mengingat cukup bagus, saat ditanya cepat tanggap ketika tidak mengerti langsung bertanya.

\section{KESIMPULAN}

Berdasarkan hasil penelitian mengenai Gambaran Fungsi Kognitif pada Lanjut Usia (Lansia) di Panti Jompo Muhammadiyah dan Yayasan Pondok Lansia Tulus Kasih, maka disimpulkan hampir setengahnya lansia mengalami Demensia Alzheimer atau gangguan kognitif berat.

\section{REFERENSI}

Arikunto, Suharsimi. 2010. Prosedur Penelitian Suatu pendekatan praktik. Jakarta: Rineka Cipta

Asih, Y. 2013. Buku Ajar Keperawatan Medikal Bedah. Jakarta: EGC.

Azizah, L. M. 2011. Kepeawatan lanjut usia.Yogyakarta: Graha Ilmu

Bhinnety, M. 2008. Struktur dan Proses Memori. Yogyakarta: Buletin Psikologi. UGM. Vol.16, No.2, 74-88.

Buntting, C.Chou KL, Amick MM, Brand J, et al. 2010. A Recommended Scale for Cognitive Screening in Clinical Trials of Parkinson's Disease. Mov Disord; 25(15): 2501-7

Departemen kesehatan RI, 2012. Profil Kesehatan Indonesia. http://wwwdepkes.go.id

Dharmono, dkk. 2008. Buku Ajar Penyakit Dalam. Universitas Diponegoro Semarang. 
Dinsos. 2013. Dinas Sosial jabar provinsi http://wwwdinsos-jabarprov.com.

Doerflinger, D. M. C. 2012. Mental status assesment in older adults: montreal cognitive assesment: moca version 7.1 (original version).

The Hartford Institute for Geriatric Nursing. Diambil dari http://consultgerirn.org/uploads/File/tryt his/try_this_3_2.pdf pada tanggal 06Juni 2014.

Foster, M.D. Norman L. 2011. Alzaimer,s \& Dementiac. The Journal of the Alzaimer's Association: Volume 10.

Freitas, S., Simoes, M. R., Alves, L., et al. 2012. Montreal Cognitive Assessment: Sociodemographic $\begin{gathered}\text { Influence } \\ \text { and }\end{gathered}$ Health Variables. Archives of Clinical Neuropsychology. 27; 165-175.

Hidayat. 2009. Metodologi penelitian Kesehatan. Jakarta: Bineka Cipta.

Hussain. H. 2008. Proses Keperawatan dan Pemeriksaan Fisik.Jakarta: EGC.

Maryam, R. Siti, dkk. 2008. Mengenal Usia Lanjut dan perawatannya. Jakarta: Salemba Medik

Maryati H, dkk, 2013, Gambaran fungsi Kognitif pada Lansia di UPT Panti Werdha Mojopahit Kabupaten Mojokerto. Journal Mentanbolisme Vol.2 No 2.

Mauk, K. L. 2010. Gerontological nursing competencies for care (2 ed). Sudbury: Janes and Barlett Publisher.
Muttaqin. A. 2008. Asuhan Keperawatan Klien dengan Gangguan Sistem Persyarafan. Jakarta: Salemba Medika.

Nugroho, W. 2008. Keperawatan Gerontik. Jakarta: Penerbit Buku KedokteranEGC.

Noorkasiani dan Tamher. 2009. Kesehatan Usia Lanjut dengan Pendekatan Asuhan Keperawatan. Jakarta: Salemba Medika.

Notoatmodjo, Soekidjo. 2010. Metode Penelitian Kesehatan. Jakarta: Rineka Cipta

Pusdatin. 2013. Buletin Jendel Pusat Datadan Informasi Kesehatan. Pusdatin Kemenkes RI. Jakarta. 2013

Panentu D, Irfan M. Uji validitas dan reliabilitas butir pemeriksaan dengan Montreal cognitive assessment versi Indonesia (MoCA-Ina) pada insane pasca stroke recovery. Palembang: Fakultas Fisioterapi Universitas Esa Unggul; 2013.

Ramdhani, N. 2012. Gambaran Fungsi Kognitif dan Keseimbangan pada Lansia di Kota Manado.

Saryono. 2011. Metodologi Penelitian Kualitatif dalam Kesehatan. Yogyakarta: Nuha Medika

Sastroasmoro. 2010. Dasar-DasarMetodologi Penelitian Klinis. Jakarta: Sagung Seto

Saladin. 2007. Anatomy and physiology the unity of from and function. 4th ed. New York: McGraw-Hill Companies inc:513516. 
Saxon, S. V., Etten, J. M, \& Perkins, E.A. (2010). Physical Change and Aging: A Guide for The Helping Professions. United States: Springer Publishing Company.

Sugiyono. 2011. Metode Penelitian Kuantitatif, Kualitatif dan $\mathrm{R} \& \mathrm{D}$. Bandung: CV. Alfabeta

Surprenant, A.M \& Neath, I. 2007. Cognitive Aging. Dalam J.M. Wilmoth \& K.F. Ferraro (Eds.). Gerontology: perspectives and issues (pp.89-110).New York : Springer Publishing Company, LLC.

Susanto. 2009. Buku Ajar KeperawatanJiwa. Jakarta Salemba Medika

Spar et al,. 2006: Kramer et al, 2006. Perubahan Kognitif.Universitas: Hasanudin.

Sya'diyah, H. 2010. Efektivitas Brain Gym dan Terapi Keperawatan Memori Games Terhadap Kemampuan Kognitif Lansia di Posyandu Lansia Puskesmas Sidosermo Surabaya. Tesis untuk Gelar Magister Keperawatan Fakultas Keperawatan Universitas Airlangga, Surabaya.

Tambunan, R.M., edisi 2. 2013, Standar Operating proseure (SOP), Jakarta: Maiestus Publishing (K)
Turana, Y. 2013. Prinsip penting Cognitive Stimulation Therapy: Buletin Jendela Data \& Informasi Kesehatan, Semester I, I, pp 19-24

Wade. C., Travis, C. 2007. Psikologi, jilid 2 (terjemahan) edisi ke 9. Jakarta: Erlangga.

Wu, M.S., Lan, T.H., Chen, C.M., Chiu, H.C., Lan, T. Y. (2011). Socio demographic and healt-related factors associated with cognitive impairmemt in the elderly in Taiwan.BMC Public Health, 11(22). doi: $10.1186 / 1471 / 2458-11-22$

Yao, S., Zeng, H., Sun, S. 2009. Investigation on status and influential factors of cognitive function of the community-dwelling elderly in Changsha City. Archives of Gerontology and Geriatrics, 49(3), 329334.

Doi:

10.1016/j.archger.2008.11.007.

Yeni, Kustanti. 2010. Kualitas Hidup Lansia dengan Terapi Komplementer Secara Mandiri.

Zainudin. Sri. 2007. Buku Ajar Keperawatan Komunitas Teori dan Praktek. Jakarta: EGC

Zulsita, 2010. Gambaran Fungsi Kognitif Pada Lanjut Usia, 